\title{
Artificial solar radiation protection of raspberry plantation
}

\author{
K. SZALAY ${ }^{1 *}$, B. KELLER ${ }^{1}$, R. RÁK ${ }^{1}$, N. PÉTERFALVI ${ }^{1}$, L. KOVÁCS ${ }^{1}$, \\ J. SOUČEK ${ }^{2}$, F. SILLINGER ${ }^{3}$ and A. JUNG
}

\footnotetext{
${ }^{1}$ National Agricultural Research and Innovation Center, Institute of Agricultural Engineering, Tessedik Sámuel Street 4, H-2100 Gödöllö, Hungary

${ }^{2}$ Research Institute of Agricultural Engineering, p.r.i., Drnovská 507, 161 01, Prague 6, Czech Republic

${ }^{3}$ Eötvös Loránd University, Faculty of Informatics, Institute of Cartography and Geoinformatics, Pázmány Péter sétány 1/A, H-1117 Budapest, Hungary
}

\section{CONFERENCE FULL PAPER}

Received: January 31, 2020 • Accepted: October 12, 2020

Published online: November 17, 2020

(C) 2020 The Author(s)

\begin{abstract}
One of the biggest challenges of raspberry production in Hungary nowadays is reducing the unfavorable effects of climate change. The maturation phase of main varieties within this region falls in a period of extremely high temperature and atmospheric drought detaining desirable fruit growth. Dedicated plant breeding alone is not enough. An immediate action is required. There has been a need for physical protection against excessive direct radiation. In order to restore, or even save the domestic raspberry production and market, introducing of greenhouse or polytunnel solutions are needed. Experimental plantations of three different raspberry varieties were set in two repetitions: covered and uncovered versions. Each cover has characteristic interaction with light which can generate different environmental conditions and also differences in plant growth and fruit quality. Besides the monitoring of elementary biological indicators, a wide range of sensors (temperature, humidity, solar irradiation) was used to identify differences and to find the optimal tunnel material for maximal plant productivity. Within the framework of the project we also tested a portable spectroradiometer and a snapshot imaging camera to study the practical value of proximal sensing in water- and photosynthetic light use efficiency and vitality mapping.
\end{abstract}

\footnotetext{
*Corresponding author. E-mail: szalay.kornel@mgi.naik.hu
} 


\section{KEYWORDS}

excessive solar radiation, raspberry plantation, proximal sensing

\section{INTRODUCTION}

There has been more and more indication of climate change related stress factors in raspberry plantations all around Hungary in the last couple of years. Farmers regularly experience reduction in plant growth, leaf area, yield, and fruit quality. Visual signs of heat stress and sunburn are often registered during the summer period's induced by excessive heat and direct radiation causing decreasing photosynthetic activity of plants. Dedicated plant breeding programs have been started to mitigate the effects of climate change (Dénes, 2016) but these programs need a long time to develop. Fighting alone by using biological ways is not enough. An immediate action is required to save the raspberry production. A physical protection against excessive direct radiation can be considered as the only way to restore the stability and quality of production in the short term. Nevertheless, returning the site of raspberry production to the forests (where the species originated from) or agroforestry systems (Nagy, 2017) can be also considered as a solution in the middle and long term. Combining solar panels with agriculture (Hajdú, 2018) in this particular place can offer an even more reasonable way to solve the question of excessive radiation. An accurately adjusted portion of radiation would be transferred to electricity while the rest can be used by the protected plantation below. In this case the shading system would produce energy which would possibly offer a more sustainable way of fighting against the effects of climate change (Deákvári, 2018) and energy scarcity. Beside the reduction of direct radiation, various shading solutions and applied materials are expected to change the spectral characteristic of incident light and so the light utilization of plants. In order to find a reasonable solution to protect the plants and increase the stability of the production, a raspberry plantation with different varieties was established. A sun protective shade tunnel system was erected to create a test site at NARIC - Fruitculture Research Institute (FRI), Fruit Culture Research and Development Institute of Fertőd, Hungary. It provides opportunity to measure and evaluate relevant biological and physical parameters playing an important role in berry production (Keller et al., 2018). Beside the conventional vegetative and productive indicators of plant growth, environmental parameters like soil and ambient temperature $\left({ }^{\circ} \mathrm{C}\right)$, humidity (\%), PYR (total solar radiation, 380-1120 nm) and PAR radiation (photosynthetically active radiation, 400-700 nm) were measured with in-situ sensors. To measure the spectral conditions (Judd et al., 1964) under the shade nets and the spectral response and features of plants with proximal sensing, a portable spectroradimeter, and a snapshot hyperspectral camera were used. Portable spectroradiometers can widely be used both in field and laboratory. It is adequate to carry out independent, fast and precise evaluations in an economic way. The device extends the range of the visible light (VIS, 350-780 nm) (Lágymányosi and Szabó, 2009) to near infrared (NIR, 780-2500 nm) region and covers the spectral range of 350-2,500 $\mathrm{nm}$ (Csorba et al., 2014). These spectrometers (Bodor et al., 2018) have successfully mastered several applications; however scanning (Firtha, 2007; Fenyvesi, 2008; Fekete et al., 2016; Badak-Kerti et al., 2018) is facing some limitations when the test object or/and camera are randomly or rapidly moving in time and space. To eliminate all these limitations, snapshot hyperspectral imaging or 
spectral frame camera technique can be successfully applied. In principle, it is capturing the entire hyperspectral image during a single integration time (one shot takes about $1 \mathrm{~ms}$ ). In agricultural field and close-field applications weight and speed are of high importance.

\section{MATERIALS AND METHODS}

Experimental plantation (Fig. 1) of three different raspberry varieties was set in two repetitions: covered and uncovered versions. Each cover has characteristic interaction with light which is expected to generate different environmental conditions and also differences in plant growth and fruit quality. In-situ environment monitoring was carried out by light, temperature and humidity sensors in different treatments (Figs. 2 and 3).

\begin{tabular}{|c|c|c|c|c|c|c|c|c|c|}
\hline \multicolumn{10}{|c|}{ Covered plantation } \\
\hline $\begin{array}{l}\frac{7}{7} \\
\frac{8}{5} \\
\frac{8}{4} \\
\frac{3}{2} \\
\frac{1}{1}\end{array}$ & $\frac{\bar{s}}{\Xi}$ & 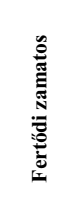 & 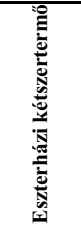 & 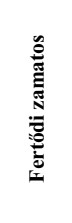 & 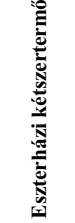 & $\frac{\vec{s}}{\underline{E}}$ & 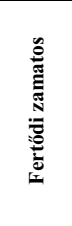 & $\frac{\bar{z}}{\Xi}$ & 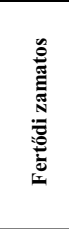 \\
\hline & Row 1 & Row 2 & Row 3 & Row 1 & Row 2 & Row3 & Row 1 & Row 2 & Row3 \\
\hline & \multicolumn{3}{|c|}{ Tunnel 1 } & \multicolumn{3}{|c|}{ Tunnel 2 } & \multicolumn{3}{|c|}{ Tunnel 3 } \\
\hline \multicolumn{10}{|c|}{ Uncovered plantation } \\
\hline $\begin{array}{l}\frac{8}{7} \\
\frac{7}{6} \\
\frac{5}{4} \\
\frac{3}{2} \\
\frac{1}{1}\end{array}$ & $\frac{\bar{s}}{\underline{s}}$ & 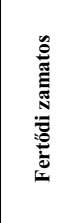 & 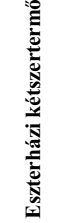 & 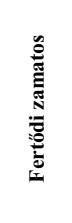 & 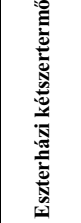 & 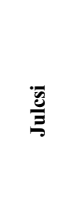 & 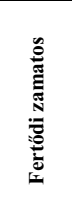 & $\stackrel{\overline{\underline{s}}}{\Xi}$ & 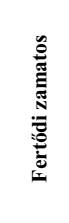 \\
\hline & $\frac{\text { Row } 1}{\text { Con }}$ & $\begin{array}{l}\text { Row } 2 \\
\text { ol for } \mathrm{T}\end{array}$ & \begin{tabular}{|l|} 
Row3 \\
nel 1
\end{tabular} & $\frac{r^{\text {Row 1 }}}{\text { Con }}$ & \begin{tabular}{|l|} 
Row 2 \\
rol for T
\end{tabular} & \begin{tabular}{|l|} 
Row3 \\
nel 2 \\
\end{tabular} & \begin{tabular}{|r|r|} 
Row 1 \\
Con
\end{tabular} & \begin{tabular}{|l|} 
Row 2 \\
rol for Tu
\end{tabular} & \begin{tabular}{|l|} 
Row 3 \\
inel 3
\end{tabular} \\
\hline
\end{tabular}

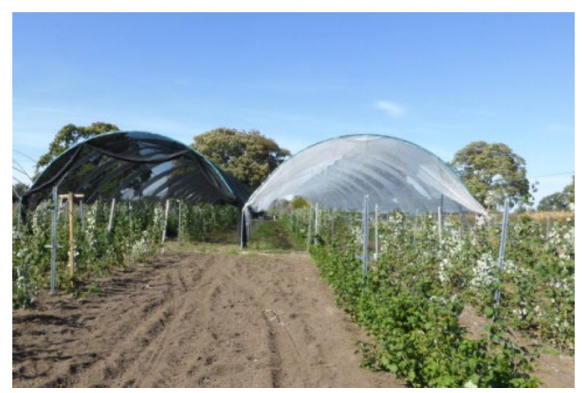

Fig. 1. Tunnels with different cover materials (shade nets) 


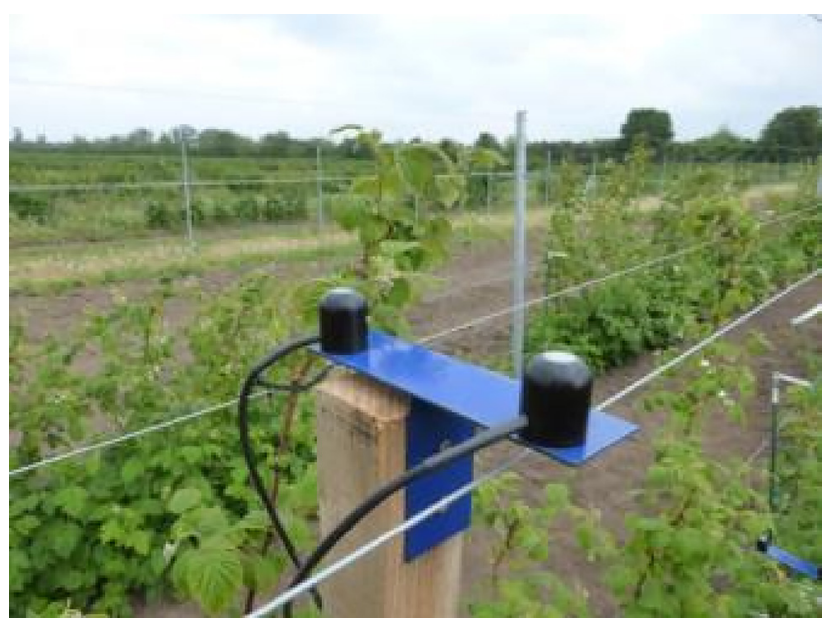

Fig. 2. PYR Apogee SP-110 360-1120 nm and PAR Apogee SQ-100 380-720 nm

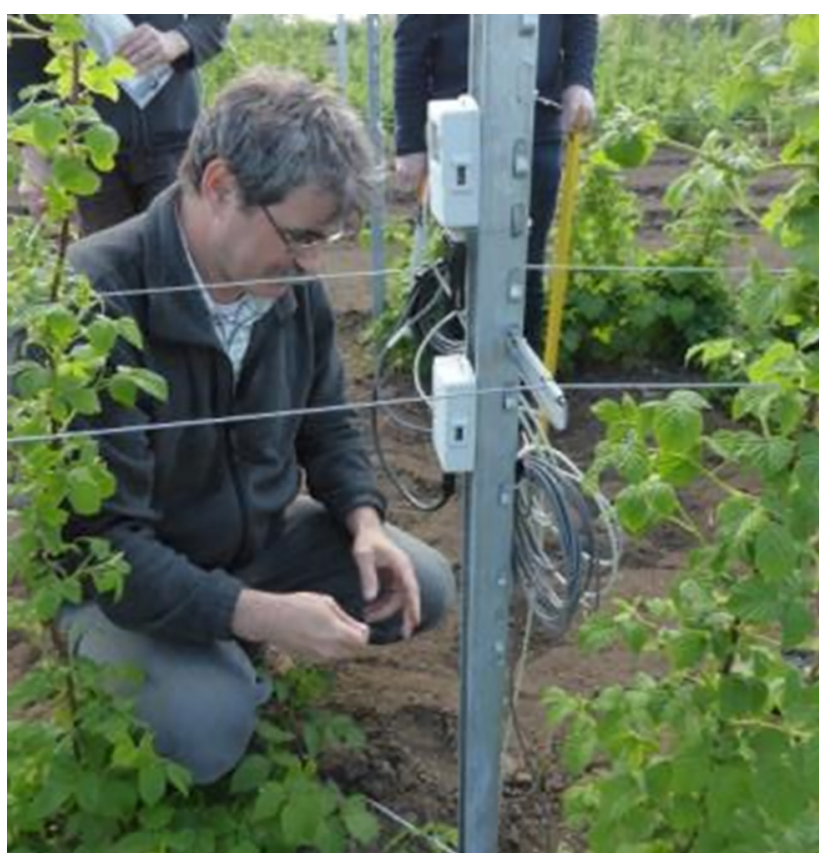

Fig. 3. Temperature sensors at: $-0.15 \mathrm{~m}, 0 \mathrm{~m}, 1.0 \mathrm{~m}, 1.8 \mathrm{~m}$. 

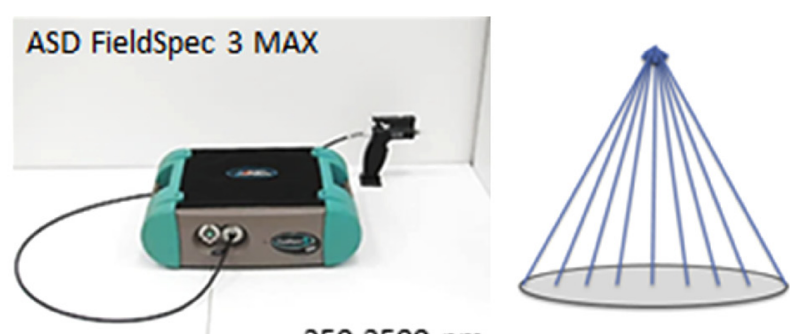

$350-2500 \mathrm{~nm}$
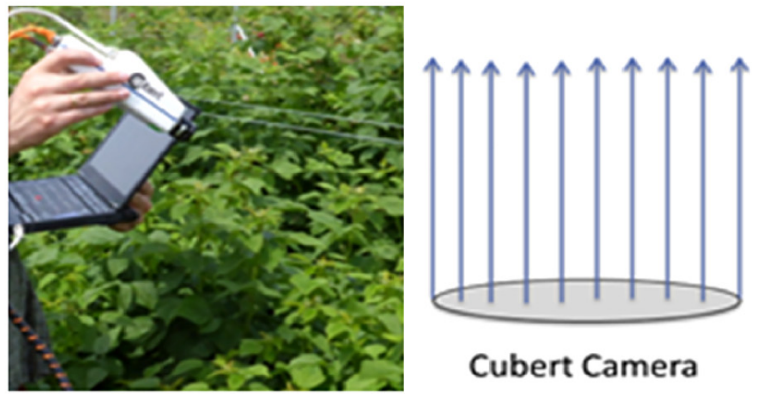

Cubert Camera

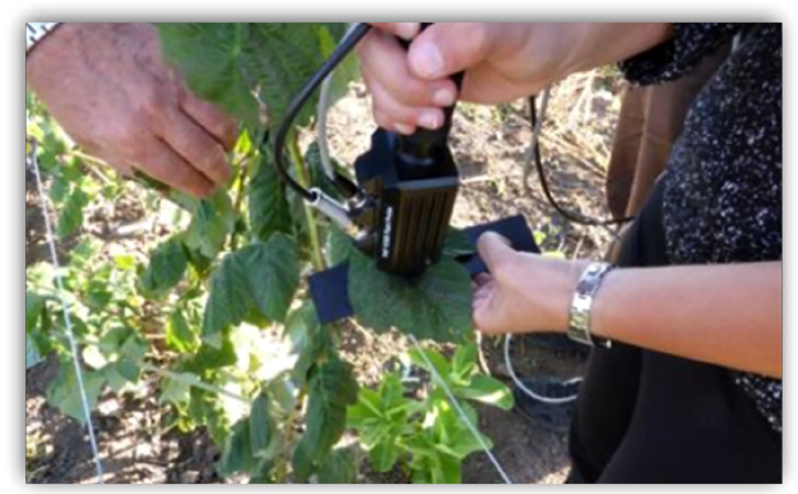

Fig. 4. ASD FieldSpec 3 MAX with PlanProbe sensor head and a Cubert snapshot camera

Portable spectral field measurements were carried out in the control area and under two different types of tunnels. Data acquisition was made by using ASD FieldSpec 3 MAX portable spectroradiometer $(350-2,500 \mathrm{~nm})$ with Plant Probe sensor and Cubert snapshot spectral camera (400-1,000 nm) on randomly selected leafs (Fig. 4) (Aasen and Bolten, 2018; Wijesingha et al., 2020; Vohland and Jung, 2020). The same reference panel was used as a standard surface reflecting $95 \%$ of all incident radiation for both acquisition methods. UV radiation was not part of this study, however, it remains an interesting research topic to study the spectral response of vegetation and the durability of the shade nets and poly-tunnels (Csatár and Fenyvesi, 2008).

In order to compare the light utilization efficiency, the water, and nitrogen management of plants under various shade nets contact measurements was used to calculate vegetation indices 
such as photochemical reflectance index (PRI), water index (WBI), and normalized nitrogen index (NDNI) with the following equations:

$$
P R I=\frac{\rho_{531}-\rho_{570}}{\rho_{531}+\rho_{570}} \quad W B I=\frac{\rho_{970}}{\rho_{900}} \quad N D N I=\frac{\log \left(\frac{1}{\rho_{1510}}\right)-\log \left(\frac{1}{\rho_{1680}}\right)}{\log \left(\frac{1}{\rho_{1510}}\right)+\log \left(\frac{1}{\rho_{1680}}\right)}
$$

\section{RESULTS}

In-situ environment sensors were continuously collecting the ambient parameters. Datasets were stored in internal memories. Data were downloaded on a regular basis and processed to plot the variation of the parameter within days, weeks, and months throughout the vegetation period (Kollányi and Szalay, 2016). Figs. 5 and 6 illustrate well the differences between the treatments in

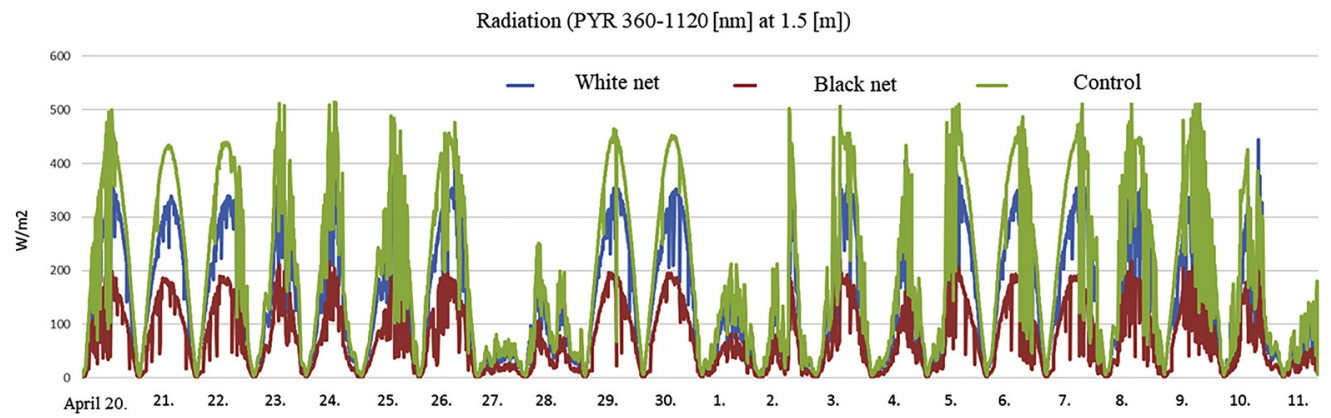

Fig. 5. Distribution of PYR radiation

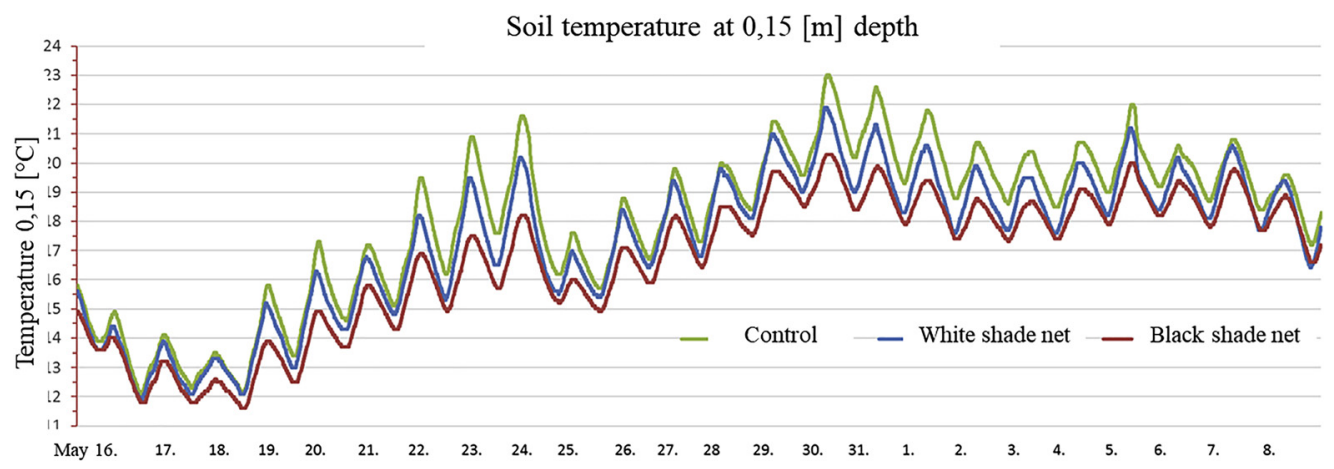

Fig. 6. Distribution of soil temperature 
a
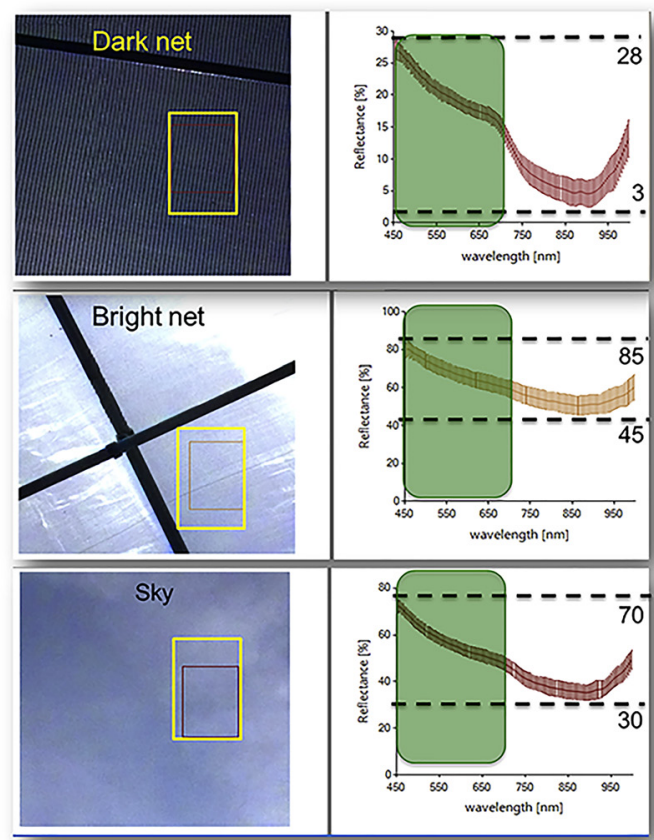

b
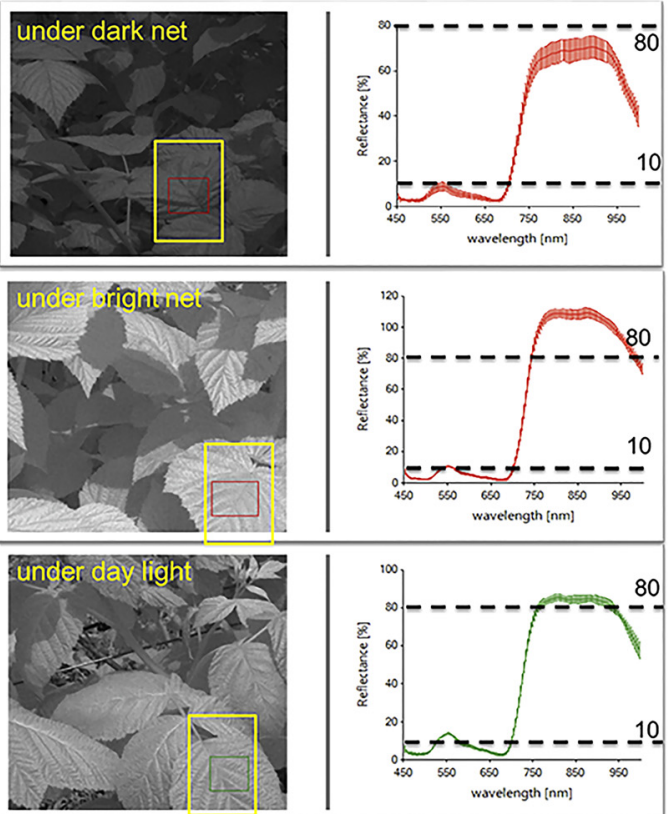

Fig. 7. (a) Hyperspectral images describing the incident and reflected radiation in the VIS and NIR region. (b) Hyperspectral images describing the incident and reflected radiation in the VIS and NIR region 
case of PYR radiation and soil temperature. These datasets very well represent the difference between environmental conditions between the shading nets and the natural radiation as well.

The processed contact spectral measurement dataset revealed a tendency of differences in case of PRI. Based on the dataset, the light utilization efficiency of all varieties under shade nets was higher than in the control plantation. WBI and NDNI did not show differences between treatments. It means the soil preparation, nutrient supply and irrigation assure the favorable homogeneity of the plantation and the only variable between treatments really is the difference in illumination. The images acquired with snapshot camera were used to evaluate the shade nets and open sky from below to describe the spectral distribution of the incident light. On the other hand, vegetation survey was performed to visualize reflective features of the vegetation and also the heterogeneity arising within plants. Differences between ratios of significant ranges playing important role in vegetation monitoring to indicate alteration of plant condition (Fig. 7a and b).

It is generally true that the main indicators of different efficiency of production technologies are yield and fruit quality. Within the frame of the research, correlations between shade nets and fruit size were observed. Julcsi reacted positively to the white colored shade net in two consecutive years with extra 72\% (2016) and 24\% of yield. Eszterházai kétszertermö reacted with extra $140 \%$ (2016) and 104\% of yield moreover with extra fruit size $4.6 \%$ (2016) and 36.69\% (2017). Fertódi zamatos did not show such a significant reaction to the treatment.

\section{CONCLUSIONS}

A portable spectroradiometer and a snapshot hyperspectral camera with more than 100 spectral channels were used to spectrally map a raspberry plantation under different type of shade nets. It was also a purpose to test and document the usability and flexibility of such techniques in collecting spectro-phenological parameters in a hand-held way. An in-situ ambient monitoring system was also set up to collect temperature, humidity and radiation data. Spectral techniques provided opportunity to reveal such differences in natural light conditions that are usually not detected by traditional weather stations and make it possible to study the correlation between light condition and plant growth in a more complex way. The results show significant differences between plantations with or without shade net cover. Measured ambient parameters and spectral analysis of the vegetation revealed differences in plant condition and indicated the effect of shade nets and also the differences between the two experimental shade net materials. Shade nets can increase the yield and also increase the average berry size but the reaction to shade nets seems to be variety-specific. Yield reacted very positively to white shade nets in the case of Eszterházai kétszertermő and Julcsi varieties, in two consecutive years. Fruit size reacted significantly positively in 2017. In case of Fertödi zamatos variety significant positive effect of shade materials was not confirmed. Variety-specific shade net-based production technology can offer a solution to improve yield, quality and production stability of raspberry. The tunnel system can be quickly deployed so it offers an immediate action to mitigate the effects of climate changes. It can also serve as an intermediate step towards agroforestry systems or remain a complementary technique with options to be used as spectral filters adjusted to plant needs or physical barriers for pests or to create a microclimate. Although the first syntheses already show useful correlations for the practice, further crop years, additional measurements and analyses are necessary to identify the best production practice. 


\section{ACKNOWLEDGMENTS}

Authors would like to express their acknowledgements to the Hungarian Ministry of Agriculture to fund this research project and to colleagues at the NARIC - Fruitculture Research Institute (FRI), Fruit Culture Research and Development Institute of Fertöd, Hungary to measure and evaluate relevant biological parameters and for the everyday hard work to maintain and preserve the experimental site. Our special thanks go to Cubert $\mathrm{GmbH}$, Germany, which made it possible to use and test the hyperspectral frame camera. Thank goes to the János Bolyai Research Scholarship of the Hungarian Academy of Sciences to support András Jung's participation in the research project.

\section{REFERENCES}

Aasen, H. and Bolten, A. (2018). Multi-temporal high resolution imaging spectroscopy with hyperspectral 2D imagers - From theory to application. Remote sensing of environment, 205, 374-389.

Badak-Kerti, K., Németh, Sz., Zitek, A., and Firtha, F. (2018). Hyperspectral monitoring of fructose content in marzipan. Progress in Agricultural Engineering Sciences, 14(s1), 79-88 https://akademiai.com/doi/ abs/10.1556/446.14.2018.S1.8.

Bodor, Zs., Adrienn Koncz, F., Said Rashed, M., Kaszab, T., Gillay, Z., Benedek, Cs., and Kovacs, Z. (2018). Application of near infrared spectroscopy and classical analytical methods for the evaluation of Hungarian honey. Progress in Agricultural Engineering Sciences, 14(s1), 11-23. https://akademiai.com/ doi/abs/10.1556/446.14.2018.S1.2.

Csatár, A. and Fenyvesi, L. (2008). Effect of UV radiation and temperature on rheological features of multilayer agricultural packaging foils. Progress in Agricultural Engineering Sciences, 4(1), 27-44. http:// akademiai.com/doi/abs/10.1556/Progress.4.2008.2.

Csorba, A., Lang, V., Fenyvesi, L., and Micheli, E. (2014). Identification of WRB soil classification units from Vis-Nir spectral signatures. In: Kim Pil Joo, and Kang Hang-Won (Eds.), 20th World congress of soil science in commemoration of the 90th anniversary of the IUSS: Soils embrace life and universe. Jeju, South-Korea 06.08-2014.06.13. International Union of Soil Sciences (IUSS), Jeju. Paper P4-539.

Deákvári, J. (2018). MaGIstra scientific forum, 2018/I. NARIC Institute of Agricultural Engineering (Personal communication 09.05.2018).

Dénes, F. (2016). Szamócatechnológia és fajtakísérletek Fertődön. Kertészet és Szölészet, 2016.08.31. 65. évf. 35. szám, 18-20. oldal.

Fekete, Gy., Issa, I., Tolner, L., Czinkota, I., and Tolner, I.T. (2016). Investigation on the indirect correlation and synergistic effects of soil $\mathrm{pH}$ and moisture content detected by remote sensing. Növénytermelés (Suppl), 203-206. 5th Alps-Adria Scientific Workshop. Mali Lošinj, Croatia.

Firtha, F. (2007). Development of data reduction function for hyperspectral imaging. Progress in Agricultural Engineering Sciences, 3(1), 67-88 http://akademiai.com/doi/abs/10.1556/Progress.3.2007.4.

Fenyvesi, L. (2008). Characterization of the soil - plant condition with hyperspectral analysis of the leaf and land surface. Cereal Research Communications, (Supp 5), 659-663.

Hajdú, J. (2018). Agro-Fotovoltaik berendezések a mezőgazdaságban. Mezőgazdasági Technika LIX. 2018.04. 18-19. 
Judd, D.B., MacAdam, D.L., and Wyszecld, G. (1964). Spectral distribution of typical daylight as a function of correlated color temperature. Journal of the Optical Society of America A, 54, 1031-1040.

Keller, B., Jung, A., Nagy, G.M., Dénes, F., Péterfalvi, N., and Szalay, K.D. (2018). Hiperspektrális távérzékelés alkalmazási lehetőségeinek bemutatása egy málna ültetvény példáján keresztül. NAIK Gödöllö, 63-72. ISBN 978-615-5748-09-7.

Kollányi, G. and Szalay, K. (2016). Fizikai paraméterek müszeres mérésének elózetes eredményei. Szamóca és málna fedett termesztése - tanácskozás és technológiai bemutató, Sarród.

Lágymányosi, A. and Szabó, I. (2009). Calibration procedure for digital imaging, Synergy and Technical Development, Gödöllö, Hungary, 30. Synergy2009 CD-ROM Proceedings.

Nagy, G.M. (2017). Agroforestry - A new start in mixed-use plantations. XVII, International Conference of Forests of Eurasia, Kazan, Oroszország, 2017.10. 02-07.

Vohland, M. and Jung, A. (2020). Hyperspectral imaging for fine to medium scale applications in environmental sciences. Remote Sensing, 12(18), 2962-2966.

Wijesingha, J., Astor, T., Schulze-Brüninghoff, D., Wengert, M., and Wachendorf, M. (2020). Predicting forage quality of grasslands using UAV-borne imaging spectroscopy. Remote Sensing, 12(1), 126.

Open Access. This is an open-access article distributed under the terms of the Creative Commons Attribution 4.0 International License (https://creativecommons.org/licenses/by/4.0/), which permits unrestricted use, distribution, and reproduction in any medium, provided the original author and source are credited, a link to the CC License is provided, and changes - if any - are indicated. (SID_1) 